\title{
América Latina / Nuestra América. El quehacer filosófico entre nosotros
}

\author{
Adriana María ARPINI \\ INCIHUSA, CONICET / UNCUYO \\ aarpini@mendoza-conicet.gov.ar

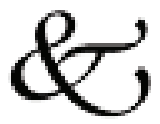

\section{Resumen}

Las palabras con las que expresamos nuestra identidad son bienes culturales, y estos, como dice Arturo Roig: "no valen por sí mismos, sino... valdrán humanamente en la medida en que los sepamos hacer valer por haberlos asumidos desde nosotros mismos como sujetos de nuestra propia Historia y con un espíritu liberador". (Roig, 2008: 26-27). Por esta razón proponemos una revisión del surgimiento y los usos que se han dado a significantes tales como "América Latina" y "Nuestra América" en circunstancias histórica concretas. Tal revisión no es ajena al ejercicio filosófico por dos razones: porque se trata de una historia de conflictos por la significación en los cuales se configura y reconfigura nuestra identidad como latinoamericanos, y porque el problema mismo es planteado como cuestión filosófica en la segunda mitad del siglo XX, especialmente en los ' 80 y '90, a propósito del quinto centenario del desembarco europeo en estas tierras. Estas discusiones están atravesadas por la cuestión colonial en la tensión globalización - localización. Hemos seleccionado un corpus que toma como referencias las obras de cuatro autores de relevancia para el tema: Arturo Ardao, Arturo Andrés Roig, Miguel Rojas Mix y Walter Mignolo.

Palabras claves: América Latina, Nuestra América, colonialidad, modernidad, identidad.

\begin{abstract}
The words with which we expressed our identity are cultural goods, and these, as Arturo Roig says: "they are not worth by themselves, but ... they will be humanly worth insofar as we knew how to cause them to be worth for having assumed them, since ourselves, as subjects of our own History and with a liberating spirit" (Roig, 2008: 26-27). Therefore we propose a revision of the sprouting and uses that have been given
\end{abstract}


to significants such as "Latin America" and "Our America" in specific historical circumstances. Such review is not alien to philosophical exercise for two reasons: because it is a matter of a history of conflicts for the significance in which our identity as Latin Americans is configured and reconfigured, and because the problem is posited itself as a philosophical issue in the second half of the 20th century, especially in the ' 80 s and ' 90 s, regarding the fifth anniversary of the European landing in these domains. These discussions are crossed by the colonial question in the globalization - localization tautness. We have selected a corpus that takes the works of four relevant authors for the topic as references: Arturo Ardao, Arturo Andrés Roig, Miguel Rojas Mix y Walter Mignolo.

Key Words: Latin America, Our America, Colonialism, Modernity, Identity.

"La única síntesis posible, donde podemos compartir nuestras tradiciones, es aquella que sin olvidar los dramatismos de la historia ni domesticar el lenguaje cuando nos referimos a sus episodios más violentos, sin negar y desvalorizar las otras tradiciones, que forman por igual la identidad americana, valoriza lo común y, reconociendo la singularidad de nuestra historia y nuestra cultura, abre un diálogo sobre el futuro" (Rojas Mix, 1991:18)

\section{"América Latina": La lucha por la significación}

Los nombres "América Latina" y "Latinoamérica" no figuran en el Diccionario de la Real Academia Española (vigésimo segunda edición). Sí figura el adjetivo "latinoamericano/na" con la siguiente descripción: "dícese del conjunto de los países de América colonizados por naciones latinas: España, Portugal o Francia". Como puede apreciarse el significado es delimitado mediante una escueta referencia histórico-geográfica que denota un punto de vista colonial en la construcción del conocimiento. Sin embargo, si realizamos un análisis desde la perspectiva del uso que se ha dado y damos en nuestros días a esos términos, advertimos que tanto sus formas sustantivas como adjetivas son el resultado de complejos y contradictorios procesos históricos, en los que la lucha por la significación ha sido un aspecto de las luchas por el auto y heterorreconocimiento, por la constitución de subjetividades, personales y colectivas, es decir, por la configuración de identidades.

Las palabras con las que expresamos nuestra identidad son bienes culturales, y estos, como dice Arturo Roig: "no valen por sí mismos, sino que son profunda y radicalmente históricos", y "valdrán humanamente en la medida en que los sepamos hacer valer por haberlos asumidos desde nosotros mismos como sujetos de nuestra propia Historia y con un espíritu liberador". (Roig, 2008: 26-27). Por esta razón, una consideración de las implicancias de estos 
términos en la caracterización del quehacer filosófico entre nosotros, requiere una revisión, aunque sea sucinta, del surgimiento y los usos que se han dado a tales significantes en circunstancias histórica concretas. Tal revisión, si bien acentúa la dimensión histórica -en la perspectiva de una Historia de las ideas-, no es ajena al ejercicio filosófico por dos razones fundamentales. Primero, porque se trata de una historia de conflictos por la significación en los cuales se configura y reconfigura nuestra identidad como latinoamericanos; historia que registra algunos momentos más o menos logrados de autoafirmación y otros en que ésta resulta defectiva. Segundo, porque el problema mismo es planteado como cuestión filosófica especialmente en la segunda mitad del siglo XX, en ocasión de profundos debates acerca de la existencia misma de una filosofía latinoamericana, durante las décadas del los '60 y '70¹; y posteriormente, des-

1 A fines de la década de 1960 y principios de los '70, al calor de un debate en que se cuestionó el sentido y la función de la filosofía tal como venía practicándose en los ámbitos académicos, tomó cuerpo el movimiento de la Filosofía de la Liberación. Su antecedente más lejano en el tiempo puede remontarse al célebre texto de Juan Bautista Alberdi "Ideas para presidir la confección del curso de filosofía contemporánea en el Colegio de Humanidades”, escrito en Montevideo, en 1840. (Alberdi, 1996: 94-100). Se ha señalado que este movimiento, si bien tuvo su origen en la Argentina, en las Jornadas Académicas de San Miguel, que se realizaron desde 1969 en la Universidad del Salvador, de los Jesuitas, alcanzó rápidamente dimensión latinoamericana. Hay que señalar el impulso que cobró el cuestionamiento acerca de una filosofía latinoamericana a partir de la polémica sostenida entre Augusto Salazar Bondy (Perú, 1925 - 1974) y Leopoldo Zea (México, 1912 - 2004), a través de sus respectivas obras ¿Existe una filosofía de nuestra América? (1968) y La filosofía americana como filosofía sin más (1969), en las que se ponía en cuestión y al mismo tiempo se buscaban respuesta a los problemas de la existencia y el carácter normativo de una filosofía latinoamericana propia. Estos problemas se sumaron a otros relativos a la cuestión de la ideología, a la función social y crítica de la filosofía, a los vínculos entre filosofía y teología, filosofía y política, a la historia de nuestras ideas filosóficas y a las cuestiones de método de un filosofar auténtico. Existieron divergencias y contradicciones entre quienes participaron de los debates. Las posiciones de Enrique Dussel (Argentina, 1934) y Arturo Andrés Roig (Argentina, 1922 - 2012), aunque no fueron las únicas, resultan paradigmáticas de la heterogeneidad del movimiento, que sin embargo tuvo una preocupación común: la liberación social, política, cultural de nuestra América. El conjunto de voces que entonces se expresaron se volcaron en publicaciones colectivas tales como la revista Nuevo Mundo, la revista Stromata, volúmenes 28 y 29, correspondientes a los años 1972 y 1973 respectivamente, el volumen Hacia una filosofía de la liberación latinoamericana (1973). En 1975 aparecieron los dos primeros volúmenes de la Revista de Filosofía Latinoamericana. En ese mismo año se publicó otro libro colectivo con el título Cultura popular y filosofía de la liberación. Una perspectiva latinoamericana (1975). Algunas obras individuales de esta época son las de Arturo Roig, Los krausistas argentinos (1969), El espiritualismo argentino entre 1850 y 1900 (1972), de Enrique Dussel, Para una ética de la liberación latinoamericana, volúmenes I y II (1973), Método para una filosofía de la liberación (1974), de Rodolfo Kusch, El pensamiento indígena y popular en América Latina (1973), de Juan Carlos Scannone, Teología de la liberación y praxis popular (1976), de Carlos Cullen, Fenomenología de la crisis moral. Sabiduría de la experiencia de los pueblos (1978), entre otras. (Cfr. Arpini, 2010 a). 
de los '80 y '90 hasta nuestros días, a propósito de las discusiones en torno al quinto centenario del desembarco de Colón en estas tierras. Discusiones atravesadas por la necesidad de reinterpretar la cuestión colonial en la tensión globalización - localización. A los efectos de esta presentación, que no pretende ser exhaustiva, hemos seleccionado un corpus que pertenece a la segunda de las etapas mencionadas. Tomamos como referencias obras de cuatro autores, de indiscutible valor sobre el tema, con quienes dialogamos. Ellos son: Arturo Ardao (1980, 1991, 1992, reunidos en edición de 1993), Arturo Andrés Roig (1981 [segunda edición 2009], 1994 [segunda edición 2008]), Miguel Rojas Mix (1991) y Walter Mignolo (2007). Los escritos escogidos salen a la luz con posterioridad a 1980 .

En su estudio sobre Génesis de la idea y el nombre América Latina, Arturo Ardao reconoce tres momentos en el proceso de gestación tanto de la idea como del nombre propio América Latina. El primero corresponde a la etapa de la Independencia, desde sus inicios en el siglo XVIII hasta el segundo tercio del siglo XIX. Para referirse a los territorios al sur de los Estados Unidos, los precursores y protagonistas de la independencia utilizaron distintos nombres: América, América del Sur, América Meridional, Hispoanoamérica, América Española, o bien Colombia -siguiendo la idea inspirada por Francisco de Miranda de la Magna Colombia-. Estos términos se ensanchaban para incluir a México y Centro América, pero se estrechaban excluyendo a la América bajo dominio de Portugal. El segundo momento, entre los años '30 y '50 del siglo XIX, aparece y crece en la pluma de escritores franceses la idea de la latinidad. En un principio se buscaba diferenciar dentro de Europa, la matriz latina de la germánica. Se trataba de una categoría histórico-geográfica que fungía, a la vez, en la filosofía de la historia, la filosofía de la cultura y la filosofía política. Su uso se amplía para distinguir las regiones del Nuevo Mundo en que se han extendido respectivamente la civilización latina y la sajona. Según Ardao, durante esta etapa se desarrolla la idea pero no aparece todavía la forma sustantiva América Latina. En la tercera etapa, a partir de la década del '50 del siglo XIX, por obra de publicistas hispanoamericanos radicados en Europa, principalmente en París, el uso frecuente de la adjetivación -América latina-, termina por sustantivarse, resultando el término compuesto América Latina, utilizado como denominación de la totalidad de la América de lengua española, portuguesa y francesa.

Dos personajes son rescatados por Arturo Ardao como figuras centrales en este proceso: Michel Chevalier ${ }^{2}$ y José María Torres Caicedo. El primero había

2 Michel Chevalier (Limoges, 1806 - Montpellier, 1879), Partidario del sansimonismo, fue seguidor de Enfantin. En 1833 viajó a Estados Unidos en misión encargada por Thiers, visitó también México y Cuba. A su regreso, difundió el librecambismo desde la cátedra de Economía Política del Colegio de Francia, que ocupó desde 1840. En 1845 se incorpora activamente a la 
recorrido los Estados Unidos, México y Cuba entre 1833 y 1835, en misión especial encargada por el entonces Ministro Thiers, para estudiar el sistema de comunicaciones del país del norte. Publicó en 1836 dos tomos de Cartas sobre la América del Norte. En la última de las Cartas, fechada en octubre de 1835, describe a los "Anglo-Americanos" como pueblo llamado a "continuar directamente, sin ninguna intervención exterior, la serie de los progresos que la civilización a la cual pertenecemos ha cumplido siempre desde que dejó el viejo Oriente, su cuna". En cambio, los "Hispano-Americanos" son a sus ojos "una raza impotente que no dejará posteridad, a menos que, por uno de esos desbordes que se llama conquistas, una ola de sangre más rica, venida del Septentrión o del Levante, llene sus venas empobrecidas" (citado por Ardao, 1993: 45). Ardao marca un giro conceptual y terminológico entre lo expresado en la última carta y el contenido de la "Introducción" 3 a las mismas, escrita poco después en la atmósfera intelectual francesa, en que predominaba el historicismo romántico y una peculiar sensibilidad sansimoniana para las cuestiones de la nacionalidad y las razas. En dicha "Introducción" Chevalier traza un plan general de la civilización cuyo fin es la unidad de la humanidad y la explotación industrial del mundo. Diferencia entre germanos (o teutones) -en cuyo seno distingue al grupo sajón y al eslavoy latinos. Al mismo tiempo señala el rol que a estos pueblos tocaría en la consecución del "equilibro del mundo". Si hasta el momento el papel preponderante ha sido de los pueblos de origen sajón, los de "cepa latina”, con Francia a la cabeza, no podían quedar atrás. Por otra parte, América es vista como el puente de enlace entre Occidente y Oriente:

"México y América del Sur están cubiertos de retoños de la civilización occidental, tanto sobre vertiente que mira al Asia, como sobre la que está frente a nosotros ... es claro que la América, colocada entre las dos civilizaciones, está reservada a altos destinos". (Chevalier, en: Ardao, 1993: 113)

política como diputado. Combatió el radicalismo social de Blanc cuando la Revolución del $\square 48$ y aceptó el golpe de Estado de Luis Napoleón. Miembro del Instituto de Francia, Consejero de Estado, ingresó en el Senado en 1860. Hombre de confianza de Napoleón III, tuvo un papel destacado en cuestiones internacionales, especialmente en ocasión de la invasión a México entre 1861 y 1867 . Durante su accionar mantuvo la aspiración sansimoniana de colonización industrial del globo por la apertura de vías de comunicación, preconizó la construcción de un canal a través del Istmo de Panamá y de un túnel submarino entre Francia e Inglaterra. Fue prolífico escritor sobre temas económicos y políticos: Cartas sobre la América del Norte (1836), Historia y descripción sobre las vías de comunicación en los Estados Unidos (1840), El Istmo de Panamá (1844), Carta sobre la organización del trabajo (1848), Examen del sistema comercial conocido bajo el nombre de sistema protector (1851), La expedición de México (1862), México antiguo y moderno (1863), El monopolio y la libertad (1867).

3 La "Introduction" a las Lettres sur l'Amérique du Nord es ofrecida por Arturo Ardao, en versión española, como Apéndice A de su libro Génesis de la idea y el nombre América Latina (1980). 
En el marco de semejante programa civilizatorio universal es que aparece el adjetivo "latina" para calificar tanto a Europa como a América, marcando una diferencia con relación a las que denomina sajona o teutónica.

"Así, hay la Europa latina y la Europa teutónica; la primera comprende los pueblos del Mediodía; la segunda los pueblos continentales del norte de Inglaterra. Ésta es protestante, lo otra católica. Una se sirve de idiomas en los que predomina el latín, la otra habla lenguas germanas.

Las dos ramas, latina y germana, se han reproducido en el Nuevo Mundo. América del Sur es, como la Europa meridional, católica y latina. La América del Norte procede de una población protestante y anglosajona”. (Ibídem: 116).

De esta manera, según Ardao, queda establecida la idea de una América latina, con el correlativo ensanche de su filiación histórica, en el juego de nuevos valores a escala universal, sin que haya cuajado todavía el nombre América Latina, para lo cual habrá que esperar hasta los años '50 del siglo XIX. Ahora bien, más relevante que la cuestión terminológica es, a nuestro juicio, constatar que la ideología civilizatoria de Chevalier, en la que se enmarca su uso del término "latina" para calificar a Europa y América, desconoce las formas de vida existentes en el continente y legitima en los hechos la invasión francesa a México entre 1861 y 1867 . Se evidencia de este modo que la significación del término es fruto de una mentalidad europea moderna, agresivamente colonial, sostenida en argumentos pretendidamente universales que invocan al progreso de la civilización, así como a la diferencia y jerarquía de las razas. ${ }^{4}$

Según Walter Mignolo, todas las reacciones contra el régimen colonial, desde la revolución haitiana de 1804, fueron reacciones contra el "colonialismo" como ideología imperial proyectada en las colonias, pero al igual que los movimientos descolonizadores posteriores a la Segunda Guerra Mundial, tuvieron una impronta política, y secundariamente económica, pero no epistémica. Esta

4 La Revista española de ambos mundos, fundada en Madrid en 1853, publicó en su primer número la traducción española de la "Introducción" de Chevalier a sus Cartas, el mismo año que se editó el volumen de Gobineau Ensayo sobre la desigualdad de las razas humanas. No fue una casualidad. El racialismo de Gobienau (Francia, 1816-1882) se apoya en una concepción puramente biológica de los seres humanos, susceptibles de ser agrupados y jerarquizados de acuerdo con rasgos comunes como el color de la piel, la fuerza física, la capacidad intelectual. Distingue en orden decreciente entre la raza blanca, la amarilla y la negra. Sólo la primera ha sido capaz de dejar marca en la historia por su capacidad de absorber y dominar a los otros grupos. Vale recordar que, a propósito de una reedición del libro de Gobineau en 1885, contemporáneamente al desarrollo de la Conferencia de Berlín -en la que se discutió el reparto de África como reaseguro del equilibrio del poder colonial-, el haitiano Joseph Anténor Firmin (1850-1911) publicó De la igualdad de las razas humanas, volumen en que no sólo refuta las tesis de Gobienau, sino que al hacerlo propone una teoría de la historia que disloca la epistemología aurocéntrica. (Cfr. Arpini, 2010 a: 327-341 y 2011: 65 - 88). 
es, según el autor, la principal diferencia con las luchas que iniciaron Aimé Césaire y Frantz Fanon y adquirieron visibilidad en la década de 1990. Aquellas estuvieron conducidas por criollos de ascendencia española, portuguesa, inglesa o africana "en cuyos horizontes no estaba la idea de que existían otras posibilidades más allá de las que ofrecía la tradición europea”; es decir que el poder cambió de manos, "pero la lógica de la colonialidad siguió siendo la misma. ... [L]os criollos de "América Latina» tuvieron que rearticular la diferencia colonial y darle una nueva forma; se convirtieron así en colonizadores internos de los indios y los negros". (Mignolo, 2007: 108-109). Para este autor, la idea de latinidad habría producido un efecto de totalidad, que invisibilizó a los indios y descendientes de africanos que vivían en América Latina. Ahora bien, la lectura que Mignolo realiza al hilo del concepto de "diferencia colonial"5, vale para una interpretación de la latinidad, la que surgió en el marco de los intereses imperialistas franceses reavivados durante el imperio de Luis Napoleón Bonaparte (Napoleón III), que tuvo en Chevalier uno de sus principales portavoces. Sin embargo es necesario introducir matices y complejizar las posibles lecturas acerca de la idea de América Latina y los usos que se hicieron del término. Tanto la expresión sustantiva "América Latina", como el adjetivo "latinoamericano" son signos linguísticos cuya significación no queda fijada de una vez y para siempre. Al contrario, las significaciones pueden cambiar y, de hecho sucede que resultan de complejos procesos de resistencia y lucha por la significación, que develan no menos agónicos procesos de afirmación, valoración y autorreconocimiento de subjetividades.

El otro personaje en que se detiene Ardao es el colombiano José María Torres Caicedo ${ }^{6}$, en cuyos escritos se verifica el pasaje de la mera adjetivación a

$5 \quad$ Alejandro De Oto señala que la política, como una demanda para la discusión de los procesos de subjetivación social, cultural, política e histórica no salió nunca del espacio de consideración teórico ni epistemológico. (Cfr. De Oto, 2008: 85-106).

6 José María Torres Caicedo (Bogotá, 1830 - Auteuil, Francia, 1889), poeta y periodista político, colaboró en El Progreso, La Sociedad Popular, La Civilización y en periódico opositor El Día. En 1850 viajó a París y luego a Londres y Estados Unidos. Se radica en París en 1853 y desde entonces se dedica a labores de escritor y periodista, a la política y la diplomacia. Como Ministro Plenipotenciario, representó a su país ante París, Londres y la Santa Sede, también representó a Venezuela en Francia y Países Bajos, al Salvador en Francia y Bélgica. Autor de diversas obras literarias -Ayes del corazón (1853), Religión, patria y amor (1863), Ensayos biográficos y de crítica literaria (1863-1868, en tres volúmenes)-; políticas -Los principios de 1789 en América (1865), Unión Latinoamericana (1865), Estudios sobre el gobierno inglés y sobre la influencia anglosajona (1868), Mis ideas y mis principios (1875, en tres volúmenes)-; jurídicas -De la pena de muerte (1864) - y económicas. Defensor de los intereses latinoamericanos en el viejo continente, fue una figura reconocida y respetada en los centros europeos de la época. El mismo M. Chevalier le dedicó un estudio con motivo de su incorporación en la Academia de Ciencias Morales y Políticas de París en 1872. (Cfr. Olalla, 2010)

LETRAS 84 (119), 2013 
la sustantivación gentilicia "América Latina", en 1956, según lo ha comprobado el filósofo uruguayo, quien sostiene que “... en el caso de nuestra América la expresión fue asumida, desde sus orígenes, por la conciencia de una nacionalidad -o supranacionalidad- que desde tiempo atrás pugnaba confusamente por definirse para de ese modo identificarse”, razón por la cual América Latina es "el único continente cuyo nombre consagrado se lo forjó él mismo en el ejercicio de su voluntad histórica”. (Ardao, 1993: 54).

En Mis ideas y mis principios, de 1875, Torres Caicedo declara: "desde 1851 empezamos a dar a la América española el calificativo de latina”. Su preocupación por establecer la diferencia con la otra América, obedece a su percepción y alarma ante el expansionismo norteamericano, evidenciado en las incursiones filibusteras de Walker en Centroamérica. Hecho que denuncia en un artículo publicado en El Correo de Ultramar, del 15 de junio de 1856. Dichas incursiones estuvieron avaladas por el presidente Pierce, quien así proclamaba "el derecho de conquista como artículo esencial de la política norteamericana”.

Ardao corrige la fecha de 1851, pues según su investigación, aunque la idea circula en los escritos del colombiano con anterioridad, la utilización del término "América latina" data del 26 de setiembre de 1856, fecha en que escribe el poema "Las dos Américas", en el cual expresa: "La raza de la América latina / al frente tiene la sajona raza"7. Este y otros ejemplos de utilización del término, tanto por parte de Torres Caicedo como de Francisco Bilbao -de quien nos ocuparemos enseguida-, son recogidos por Ardao con el propósito de refutar la creencia de que la denominación habría surgido en la década del '60, por obra de los ideólogos de Napoleón III con el fin de justificar su aventura mexicana, como errónea e intencionadamente ha sostenido el investigador norteamericano John Phelan en un texto publicado en 1968 con el título Panlatinismo, la intervención francesa en México y el origen de la idea de Latinoamérica. Dice Ardao:

"Francesa en sus orígenes [en alusión a Chevalier] la primera idea de latinidad de nuestra América, fue, en cambio, hispanoamericana y antiimperialista [en alusión a Torres Caicedo y Bilbao], también en sus orígenes, la denominación continental a la que ella condujo". (Ibídem: 68).

En 1961, desde París, Torres Caicedo lanza las Bases para una liga Latinoamericana y posteriormente publica Unión Latinoamericana (1865) en que realiza una ferviente predica a favor de la idea expresada en el título del libro y en contra de la doctrina del "destino manifiesto" reactivada por el Presidente Buchanan. Se suma luego la publicación de su ensayo sobre La América Anglosajona y la América Latina (1882), en el que sostiene:

7 El poema fechado en Venecia el 26 de setiembre de 1856, fue publicado en El Correo de Ultramar el 15 de febrero de 1857. A fines de ese mismo año, no por casualidad, Francisco Bilbao lo reproduce en La Revista del Nuevo Mundo, que editó en Buenos Aires entre julio y diciembre. 
"Congresos para la Unión Latino-Americana, cuantos se quieran: la idea de la Unión será un hecho histórico; pero esos congresos deben reunirse en territorio latinoamericano, para buscar los medios de preservarse, de unirse y de hacer frente a cuantos en Europa o América tengan la pretensión de subyugarnos. Después de las teorías del "Destino Manifiesto" proclamadas con más energía en 1881, el Congreso de las dos Américas en Washington sería un error político y diplomático de los latino-americanos. Y sin embargo nada anhelamos tanto como la estrecha y cordial amistad entre la Unión Norteamericana y las repúblicas antes colonias de España; pero esa unión que sea en el seno de la igualdad, de la reciprocidad, de la lealtad, y después de haber sido retractadas las teorías de los Brown, Seward, Blaine”. (Torres Caicedo, 1882, en Ardao, 1993: 152).

Posteriormente, en un discurso pronunciado en homenaje a José de San Martín, deja claro que su idea de América latina se inscribe en la tradición de unidad continental e independencia abierta por los libertadores:

"Para mí, colombiano, que amo con entusiasmo mi noble patria, existe una patria más grande: la América Latina ... Hay hombres que califican de utopía el pensamiento fecundo de Bolívar de formar una confederación latino-americana. Los que así hablan olvidan la historia de estos países ..." (Torres Caicedo, $1886^{8}$, en Ardao, 1993: 153).

Aun cuando Ardao menciona a Francisco Bilbao ${ }^{9}$ como contemporáneo de Torres Caicedo en el uso del término "América Latina", ha sido Manuel Rojas Mix quien siguiendo la pista de la utilización del término en los escritos bilbaínos, deja establecido que el chileno antecede al menos en tres meses al colombiano en su uso. Lo hace en una conferencia dada en París el 24 de junio

8 Discurso en homenaje a José de San Martín (París, 26 de febrero de 1886), publicado en Revue Sud-Américaine, París, no 89, 1886, p. 390.

9 Francisco de Sales Bilbao (Santiago de Chile, 1823 - Buenos Aires, 1865), fue escritor, filósofo y político chileno. De niño acompañó a su padre -político liberal enrolado en las filas de los "pipiolos" durante su exilio en Lima. De regreso, vivió la efervescencia intelectual de los años 40. Fue secretario de la Sociedad Literaria, en cuyo periódico, El Crepúsculo, publicó en 1844 su primer escrito famoso "Sociabilidad Chilena", en el que criticaba agudamente el estado de postración social, miseria, postergación, pobreza de la mayoría de la población, haciendo cargo a la herencia española y a la Iglesia Católica, símbolos de barbarie enquistada en Chile. En 1845 emigró a Francia, donde vivió los episodios de la Revolución del 48. En 1849 regresa a Chile y crea, junto a Santiago Arcos y Eusebio Lillo, en Santiago la Sociedad de la Igualdad, que fue quizás el primer antecedente de organización de movimientos proletarios en América latina. Nuevamente en el exilio, primero en Lima y luego, entre 1855 y 1857, en Inglaterra, Francia, Bélgica, Italia. De esta época datan sus escritos en los que insta a la unión de los pueblos de "nuestra América": Movimiento de los pueblos de la América meridional y la conferencia "Iniciativa de las América", ambas de 1856. En 1857 se dirige a Buenos Aires donde reside hasta su muerte. Se involucró a favor del movimiento federal. Colaboró con diversos periódicos. Publicó La América en Peligro (1862), El evangelio americano (1864). (Cfr. Jalif de Bertranou, 2003). 
de 1856, conocida con el título "Iniciativa de la América" (Bilbao, 1866: I, 285304). En ella retoma la propuesta de Bolívar de reunir un Congreso Federal de las Repúblicas del Sur, a las que también denomina "Estados Des-Unidos del Sur", "mundo de Colón", "América de Maipo, Carabobo y Ayacucho", "nuestra América". Aunque Bilbao fuera "un marginal de la historia", silenciado por filósofos e historiadores, y aunque cayera sobre él la acusación de "agitador, blasfemo e inmoral" 10 , no se justifica-sostiene Rojas Mix- minimizar su papel en la formación del término con que hoy reconocemos nuestra identidad. No sólo porque fue el primero en utilizarlo, sino porque le dio su sentido actual, diferente de la noción de latinidad que entonces era más frecuente -la difundida por Chevalier-. Bilbao utilizó el nombre "América Latina" como paradigma de identidad anticolonial y antiimperialista. Cuando advierte que se usa para legitimar el colonialismo francés, comienza a desconfiar del vocablo y prácticamente lo abandona. Desde el periódico argentino La Tribuna, el único de ese país que se manifestó en oposición a la invasión, advertía sobre el peligro que se cernía sobre América con las ideas imperiales de Maximiliano. El libro La América en peligro, que recoge sus artículos sobre el tema, fue prohibido por el Obispo de Buenos Aires. (Rojas Mix, 1991: 343 y ss).

En su conferencia del 24 de junio de 1856, Bilbao descarta una idea falaz de unión que supone la centralización, la monarquía, la conquista, el sometimiento y el despotismo, todo lo cual viola la independencia de las razas "en obsequio a la codicia, vanidad u orgullo de las naciones fuertes". "La unidad que buscamos -dice- es la asociación de las personalidades libres, hombres y pueblos, para conseguir la fraternidad universal" (Bilbao, 1866: I, 289). Frente al peligro de los imperios que pretenden la dominación del mundo -el Imperio Ruso, a cuya pretensión hegemónica llama "barbarie absolutista", y los Estados Unidos, cuyo individualismo y expansionismo califica de "barbarie demagógica"-, Bilbao invoca a la "raza Latino-Americana para que lleve adelante su propia iniciativa:

"Ha llegado el momento histórico de la unidad de la América del Sur, se abre la segunda campaña, que a la independencia conquistada, agregue la asociación de nuestros pueblos". (Ibídem: 290).

"Tenemos que desarrollar la independencia, que conservar las fronteras naturales y morales de nuestra patria, tenemos que perpetuar nuestra raza Americana y Latina, que desarrollar la República, desvanecer las pequeñeces nacionales para elevar la gran nación Americana, la Confedera-

10 Clara Alicia Jalif de Bertranou recuerda que con motivo de la publicación de su escrito "Sociabilidad chilena”, en 1844, en el periódico mensual de la Sociedad Literaria El crepúsculo, Bilbao fue expulsado del Instituto Nacional de Chile acusado de "agitador, blasfemo e inmoral". (Cfr. Jalif de Bertranou, 2010, 255-261) 
ción del Sur. Tenemos que preparar el campo con nuestras instituciones y libros a las generaciones futuras. Debemos preparar esa revelación de la libertad que debe producir la nación más homogénea, más nueva, más pura, extendida en las pampas, llanos y sabanas, regadas por el Amazonas y el Plata y sombreadas por Los Andes. Y nada de esto se puede conseguir sin la unión, sin la unidad, sin la asociación". (Ibídem: 291, cursiva nuestra).

Bilbao critica las nociones de progreso y civilización, pues considera que el progreso es vulgarmente tomado como un sofisma que hace desaparecer bienes, pueblos y verdades, y hacer retroceder la dignidad, la fraternidad y la prosperidad de las naciones. Ambas ideas - progreso y civilización- son falaces cuando lejos de perseguir el bien universal, se utilizan para legitimar una política imperial. Frente a esto, ¿qué es lo que la raza Latino-Americana puede colocar en la balanza para contrapesar el expansionismo del norte y el estancamiento de Europa?

"Vive en nuestras regiones algo de esa antigua humanidad y hospitalidad divinas; en nuestros pechos hay espacio para el amor del género humano. No hemos perdido la tradición de la espiritualidad del destino del hombre. Creemos y amamos todo lo que une; preferimos lo social a lo individual, la belleza a la riqueza, la justicia al poder, el arte al comercio, la poesía a la industria, la filosofía a los textos, el espíritu puro al cálculo, el deber al interés, ... y el negro, el indio, el desheredado, el infeliz, el débil, encuentra en nosotros el respeto que se debe al título y la dignidad del ser humano". (Ibídem: 296, cursiva nuestra).

La América libre es un programa, que incluye: formar un congreso americano, conceder la ciudadanía universal, un código internacional, un pacto de alianza federal y comercial, la abolición de las aduanas, uniformización del sistema de pesos y medidas, creación de un tribunal internacional, un sistema de colonización de las grandes áreas desiertas, educación universal y civilización para los bárbaros (aborígenes) ${ }^{11}$, la formación del libro americano y la creación

11 ¿Cómo interpretar la expresión "civilización para los bárbaros" en el texto bilbaíno? Una lectura superficial lo pondría en línea con una consideración jerarquizante e incluso racialista de la dicotomía "civilización - barbarie", a la manera de Sarmiento. Sin embargo es posible otra lectura más acorde con el pensamiento de Bilbao. Según entendemos, Bilbao considera que es necesario colocar a todos "indios, negros, desheredados" en condiciones de utilizar los medios de la civilización para la defensa de lo propio y de lo común. En sentido semejante se expresan Simón Rodríguez, Manuel de Salas, Eugenio María de Hostos, entre varios más. Otro tanto cabe decir de la iniciativa de crear una Universidad Continental. Estas ideas responden al llamado bolivariano de unidad de nuestra América ante los peligros de quedar sometida a los imperialismos. La creación de una Universidad Latinoamericana Continental, cuyo objetivo debía ser el conocimiento de la realidad latinoamericana cobró fuerza a fines del siglo XIX y durante el primer tercio del XX. Además de Bilbao, que anticipa la idea, se refieren a ella, entre otros, el cubano José Martí y el argentino Julio Ricardo Barcos. (Cfr. Roig, 1979) 
de una universidad, de un diario y de fuerzas armadas comunes, etc. (Cfr. Ibídem: 300-302).

A diferencia de Ardao, cuyo hilo argumentativo está centrado en el interés por datar el uso del término "América Latina", en su forma adjetiva o sustantiva, para Rojas Mix el problema gira en torno de "una incertidumbre de identidad" que vive nuestra América:

"Diversos sectores se identifican con distintas imágenes culturales. La identidad está asociada a una iconografía que expresa los conflictos coloniales y las estructuras sociales y de poder. En este conflicto de identidades se enfrentan los latinoamericanos al desprecio racial, a la discriminación social e, incluso, al imperialismo cultural, que a fines del siglo pasado [XIX] les sustrajo el derecho a un nombre genérico, el de llamarse simplemente América, obligándolos a subdeterminarse. ... Por ello, para no confundir las americanías ... [u]tilizamos ... neologismos como el de estadounidenses, usamericanos o el adjetivo usaico, porque el gentilicio americano nos pertenece a todos, a los del norte y a los del sur" (Rojas Mix, 1991: 24)

A partir de los textos de Bilbao, Rojas Mix determina que América latina es una idea que se define, más que por la lengua, por el sentimiento anticolonial y antiimperialista; idea que ha sido retenida por los latinoamericanos en el sentido de detener el avance del mundo sajón en «nuestra América» (Cfr. Rojas Mix, 1991: 356).

Por su parte Mignolo considera que las tesis de Bilbao constituyen una excepción dentro de la lógica de la modernidad/colonialidad en la que se inscribe el concepto de la "latinidad". Acerca del cubano José Martí, de quien nos ocuparemos más adelante, sostiene que defendió una visión de la latinidad que se contrapone a la de Torres Caicedo y a la de Juan Bautista Alberdi. En línea con Martí estarían, según Mignolo, José Carlos Mariátegui, en la década de 1920 y Enrique Dussel a partir de 1960. Como quedó señalamos, esta breve genealogía es una posible lectura de las disputa por la significación. Existe, al menos, otra lectura posible, que se inscribe en la tradición abierta por Bolívar de unión latinoamericana, en la que Bilbao no es una excepción, y en la que Martí, Torres Caicedo y Alberdi, si bien sostienen posiciones diferentes, no se contraponen necesariamente en todos los puntos. En el reverso del significante "América Latina", los hilos del entramado presentan matices que vale la pena considerar y que permite reconstruir una genealogía más rica y mucho más poblada de nombres. Además, Los términos "América Latina" y "Latinoamérica" no expresaron en las voces de Bilbao y Torres Caicedo un proyecto totalmente nuevo de unidad e identidad continental. Tal idea estuvo presente en Francisco Miranda, Simón Bolívar, José de San Martín; quienes no concebían patrias chicas que no estuvieran integradas en la Patria Grande. 
Cabe recordar algunos pasajes de la Carta de Jamaica (Kingston, 1815): "Yo deseo más que otro alguno ver formarse en América la más grande nación del mundo, menos por su extensión y riqueza que por su libertad y gloria”. Más adelante:

"Qué bello sería que el Istmo de Panamá fuese para nosotros lo que el de Corinto para los griegos. Ojalá que algún día tengamos la fortuna de instalar allí un augusto Congreso de los representantes de las Repúblicas, reinos, imperios, para tratar y discutir sobre los altos intereses de la paz y de la guerra con las naciones de otras partes del mundo. Esta especie de corporación tendría que tener lugar en alguna época dichosa de nuestra regeneración".

La convocatoria para el Congreso la realizó Bolívar desde Lima, en diciembre de 1824 y en ella se especifican las funciones que debía cumplir el mismo: servir de consejo a los grandes conflictos, de punto de contacto con los peligros comunes, de intérprete de los tratados públicos ante posibles dificultades, de conciliación de las diferencias. Bolívar estaba pensando una reunión que dejara en funciones un organismo permanente, una liga de naciones hispanoamericanas independientes, a la que denominó "Liga Anfictiónica". (Cfr. Roig, 2008). Con el nombre "América Meridional", Bolívar se diferenciaba de la América del Norte. En este argumento se apoya Rojas Mix para denunciar, como también lo hace Arturo Roig, cierta versión tergiversada del ideario bolivariano, que busca hacerlo compatible con los intereses expansionistas de Estados Unidos e incorporarlo como antecedente del "panamericanismo".

El panamericanismo tuvo su origen al mismo tiempo que se gestaba el hispanoamericanismo bolivariano, pero tiene sus raíces en el monrroismo. En 1823, el presidente James Monroe declaró ante el Congreso de los Estados Unidos, que el continente americano no sería lugar de colonización de las grandes potencias europeas nucleadas en la Santa Alianza. Su posición quedó sintetizada en la fórmula "América para los americanos", cuya ambiguiedad no tardó en ponerse de manifiesto con las ocupaciones y despojos sufridos por México, Cuba, Puerto Rico y Panamá durante el siglo XIX.

En la convocatoria para la Conferencia Internacional Americana que se reunió en Washington entre octubre de 1889 y abril de 1890, el senador James Blaine la designa como "Primera Reunión Panamericana". Desde que Blaine ocupó la Secretaría de Estado bajo la presidencia de James A. Garfield, en 1881, se adoptó una política agresiva con relación a las Repúblicas de Centro y Sur América, sostenida por una interpretación de la Doctrina Monrroe, que proponía un sistema hemisférico basado en el intercambio pacífico, procedimientos de arbitraje y conferencias para tratar los problemas interamericanos en general. En realidad su objetivo fue la expansión para satisfacer las necesidades 
comerciales de los Estados Unidos, urgido de mercados exteriores donde colocar los excedentes de su industria en crecimiento. Expansionismo, surgido de una alianza oscura entre la política y los negocios, que justificó la ocupación, anexión y absorción territorial.

Un testigo privilegiado de la reunión de Washington fue José Martí (La Habana, 1853 - Dos Ríos, 1895), quien escribió las Crónicas del Congreso para el diario argentino La Nación, desde noviembre de 1889 hasta agosto de 1890, a las que se suma su informe sobre "La conferencia monetaria de las Repúblicas de América, publicada en La Revista Ilustrada de New York, en mayo de 1891. En sus escritos el cubano puso de manifiesto las contradicciones entre las declaraciones, las intenciones y los hechos:

“... congreso que llaman aquí de Panamérica, aunque ya no será de toda, porque Haití, como que el gobierno de Washington exige que le den en dominio la península estratégica de San Nicolás, no muestra deseos de enviar sus negros elocuentes ...; ni Santo Domingo ha aceptado el convite porque dice que no puede venir a sentarse a la mesa de los que le piden a mano armada su bahía de Samaná. ... Las entrañas del congreso están como todas las entrañas, donde no se las ve" (Martí, 2005: 50-51).

En el informe sobre "La Conferencia monetaria de las Repúblicas de América”, advierte Martí acerca de los peligros de una unión espuria:

"En la vida común, las ideas y los hábitos han de ser comunes. ... Los países que no tienen métodos comunes, aun cuando tuviesen idénticos fines, no pueden unirse para realizar su fin común ... [En Estados Unidos] creen en la necesidad, en el derecho bárbaro, como único derecho: "esto será nuestro porque lo necesitamos». Creen en la superioridad incontrastable de la raza anglosajona contra la raza latina. Creen en la bajeza de la raza negra, que esclavizaron ayer y vejan hoy, y de la india, que exterminan. ... ¿ ipueden los Estados Unidos convidar a Hispanoamérica a una unión sincera y útil para Hispanoamérica? ¿Conviene a Hispanoamérica la unión política y económica con los Estados Unidos?

Quien dice unión económica, dice unión política. El pueblo que compra, manda. El pueblo que vende, sirve. Hay que equilibrar el comercio para asegurar la libertad. El pueblo que quiere morir, vende a un solo pueblo, y el que quiere salvarse, vende a más de uno". (Martí, 2005: 59).

Como consecuencia de la Conferencia se creó, en la órbita del gobierno de Washington, la Oficina Comercial de las Repúblicas de América el 14 de abril de 1890, la que posteriormente fue bautizada "Unión Panamericana", con ello quedó oficializado el uso del término y el día 14 de abril fue incorporado como día Panamericano en el calendario de festejos escolares de muchos países latinoamericanos durante buena parte del siglo XX. Rojas Mix recuerda la experiencia en un relato autobiográfico, en el que narra que siendo niño asistía 
a la escuela de la Compañía minera donde trabajaba su padre, en Potrerillos, un pueblo del norte de Chile. Allí se festejaba el 14 de abril:

"Era -nos explicaban en la escuela de la Compañía- un día de unidad de las Américas. «Pan» quería decir «todos»: de unidad con los Estados Unidos, de donde venían aquellos niños rubios. Eso era el "panamericanismo». Solo más tarde supe, por un chiste, que lo malo del "panamericanismo» es que para la América española "pan» significa algo muy distinto que para los ingleses. Pan es la comida que hay que ganar todos los días, mientras que en inglés, «pan» es la sartén, que ellos tienen por el mango" (Rojas Mix, 1991: 14).

No cabe la confusión entre "panamericanismo" y "latinoamericanismo". Cada uno de estos términos tiene una historia que los diferencia y señala proyectos antagónicos. Sostiene Roig que:

"El latinoamericanismo es un ideario cosmopolita y ecuménico, ejercido desde una realidad histórica, que es la de nuestros pueblos con sus derechos tan inalienables como los de los demás, ... pretende ser un ideario de liberación que abra puertas para formas integrativas más elevadas" (Roig, 2008: 42).

Y con relación a la palabra "Latinoamérica" enfatiza que:

"nació en la primera mitad del siglo XIX dentro de dos movimientos ideológicos incompatibles. Fue acuñado el término en 1851 (sic) ${ }^{12}$ por el chileno Francisco Bilbao y el bogotano José María Torres Caicedo, en quienes pesaba de un modo muy fuerte el enfrentamiento de nuestros países hispanoamericanos con los Estados Unidos". (Roig, 2008: 35).

No escapaba a sus mentes lúcidas los intentos de ocupación y despojo que asomaban tras el fomento de los separatismos de Panamá y Texas (esta quedó anexada a los EEUU en 1845, y en 1847 de produce el asalto a la ciudad de México y la sesión forzosa de la mitad de su territorio a los EEUU). Entre 1861 y 1867 se produce la invasión francesa a México. Bilbao y Torres Caicedo usaron el término en contra de la presencia de franceses, austríacos y españoles en tierras mexicanas. (Roig, 2008).

El suelo del que se nutre el ideario latinoamericano incluye un programa de independencia cultural. El cual constituye uno de los movimientos de identidad más ricos y diversificados del mundo contemporáneo. Sus inicios datan de la segunda mitad del siglo XVIII, época en que surge la noción de "patria". Era un programa difuso y complejo que buscaba un autoconocimiento, una autoafirmación dentro del autonomismo. Los sabios Mutis y Caldas, los jesuitas expulsos y escritores del siglo XVIII dieron forma a ese primer programa que Roig denomina de "autonomía cultural". Programa que fue reformulado de

12 Como quedó demostrado por Arturo Ardao y Miguel Rojas Mix, el año correcto es 1856. 
conformidad con las transformaciones del entramado socio-histórico. Finalizadas las Guerras de Independencia, el programa ilustrado se convirtió en exigencia de "emancipación mental", es decir, de liberación de la mentalidad y las costumbres de la vida colonial. Fue el proyecto romántico, que se debatió en la tensión entre la búsqueda de la modernización y una toma de distancia, para evitar ingresar a ella de prestado. Aquel ideario incluye también un importante movimiento de "americanismo literario", que constituye otra línea de desarrollo de la afirmación de nuestra identidad. (Cfr. Roig, 2008; Rojas Mix, 1991).

\section{Nuestra América}

Tal vez haya sido Francisco Bilbao el primero en utilizar la expresión "Nuestra América”, lo que es seguro es que quedó definitivamente inscripta como sello de identidad desde que José Martí la utiliza pata titular su breve pero contundente ensayo publicado en La Revista Ilustrada de New York, el 10 de enero de 1891, y luego, el 30 de enero del mismo año en El Partido Liberal de México. Por su capacidad para enfrentar una serie compleja de tensiones situadas geográfica y epocalmente en América Latina pero con alcance mundial, el escrito de Martí "Nuestra América" ha recibido diversas caracterizaciones. Ha sido considerado como un tratado del buen gobierno, en cuanto señala las características que ha de reunir el gobernante de los países nuevos de América (Cfr. Ramos, J., 1989); como un proyecto de sociedad, de identidad y de unidad, con raíces en el pasado y en el futuro, y fundador del concepto moderno de América Latina porque supera la visión de comunidad linguiística o puramente cultural (Cfr. Rojas Mix, 1991); también se ha dicho que en él es posible encontrar una base capaz de equilibrar los factores conflictivos del procesos de modernización y frenar el expansionismo yankee, en la medida que instala discursivamente un nuevo sujeto cultural, un "nosotros latinoamericano" (Cfr. Ossandón Buljevik, 2003); se lo ha calificado de manifiesto, por su potencial movilizador de voluntades políticas (Cfr. Santos, 2004); ha sido, en fin, considerado como uno de los textos fundantes del pensamiento filosófico latinoamericano, porque constituye una afirmación de la propia valía de ese "nosotros latinoamericano", que estima valioso reflexionar sobre sí mismo (Cfr. Roig, A., 2000).

En efecto, se trata de un texto clásico del pensamiento latinoamericano. Mediante el recurso a diversas figuras, el cubano ejerce la sospecha sobre la racionalidad de la existencia colonial tal como se presenta y presiona sobre los límites de lo dado, mostrando, por un lado, la contingencia de las relaciones sociales presentes y la arbitrariedad de la legitimación filosófica y política de las mismas; y por otro lado, la posibilidad de una construcción alternativa. Tanto el "aldeano vanidoso", satisfecho en la contemplación de su propia fortuna, 
como "los sietemesinos", que han perdido la fe en sí mismos seducidos por la ilusión de experimentar una vida que no les pertenece, y el "criollo exótico", que tiene la ilusión de adaptar las formas de vida de nuestra América a modelos tomados de Francia o Estados Unidos, como son los casos de Sarmiento o Alberdi -en la etapa de las Bases (1852)- (Cfr. Rojas Mix, 1991: 155-165), todos ellos están desorientados, enajenados, sin poder hacer pie en su propia realidad. Frente a ello, dice Martí:

"Lo que quede de aldea en América Latina debe despertar ... Trincheras de ideas pueden más que trincheras de piedra ... Una idea enérgica, flameada a tiempo ante el mundo, para, como la bandera mística del juicio final, a un escuadrón de acorazados. Los pueblos que no se conocen han de darse prisa para conocerse ... iLos árboles han de ponerse en fila para que no pase el gigante de las siete leguas! Es la hora del recuento, de la marcha unida, y hemos de andar en cuadro apretado, como la plata en las raíces de Los Andes". (Martí, 2005: 8).

Dos aspectos surgen de las palabras de Martí que, a nuestro juicio, podrían sentar las bases de un nuevo paradigma filosófico-político. Por una parte, términos como "despertar", "trincheras de ideas" hacen referencia a un proceso cognitivo, reflexivo y crítico que posibilita la construcción de unas mediaciones más adecuadas para el conocimiento de nuestra propia realidad -sería una manera de zanjar la "diferencia epistémica" señalada por Walter Mignolo (Cfr. Mignolo, 2007)-. Por otra parte, las imágenes de "recuento", "marcha unida" y "andar en cuadro apretado", aluden a una determinada manera de encarar la acción, uno junto a otro -no uno delante de otro, ni sobre otro-. Podría interpretarse como una incitación a deponer intereses particulares ante la necesidad de unirse frente al enemigo común y poderoso. Pero, además de su carácter defensivo frente al "gigante de las siete leguas", estas imágenes tienen peso propio cuando se trata de afirmar el valor y los derechos de los hombres en orden a la emancipación. En efecto, Martí señala la urgencia de superar los hábitos enquistados durante la colonia que negaron el derecho del hombre al ejercicio de su propia razón. "La razón de todos en las cosas de todos" (Martí, J.-, 1975: 19). Martí no está pensando desde el marco estrecho de una razón meramente reguladora, ordenadora del caos de la diversidad. Se trata, por el contrario del recuento de lo diverso en cuanto tal, es decir, del reconocimiento de la existencia de experiencias vitales diferentes y de formas diferentes de organización racional de la vida. Unir no es sinónimo de uniformar. La frase alude a la participación directa, de todos y cada uno a partir de sus diferencias, en las decisiones que afectan a todos. La ceguera epistemológica y axiológica frente a las diferencias es para el cubano una "incapacidad" aun cuando se oculte bajo gruesas capas de erudición: 
"Las repúblicas han purgado en las tiranías su incapacidad para conocer los elementos verdaderos del país. ... Conocerlos basta, sin vendas ni ambages: porque el que pone de lado por voluntad u olvido, una parte de la verdad, cae a la larga por la verdad que le faltó... Viene el hombre natural, indignado y fuerte, y derriba la justicia acumulada de los libros porque no se la administra de acuerdo con las necesidades patentes del país" (Ibídem, 10).

En esta imagen se puede apreciar, como lo ha señalado Arturo Roig, una forma específica de ejercicio dialéctico: la dialéctica de la emergencia, cuyo punto de partida está dado por el reconocimiento de las propias necesidades. La primera necesidad es precisamente la de afirmarse como valiosos y el considerar valioso el propio conocimiento (Roig, A., 2002: 107 - 130). Se trata, en otras palabras, del reconocimiento de la propia dignidad; pero éste sólo es posible sobre la base del mutuo reconocimiento, es decir del reconocimiento del otro en su diferencia, en virtud de que la dignidad humana es un fin. Lo dicho vale tanto para las relaciones entre individuos como entre pueblos y culturas. La determinación de las propia necesidades y su objetivación, especialmente a través del lenguaje, contribuyen a definir los criterios para su satisfacción, los que están siempre culturalmente modelados.

Se trata, no de copiar, sino de crear. Frente a las figuras enajenadas del "aldeano vanidoso", de "los sietemesinos" y del "criollo exótico" Martí propone la del "hombre natural". Es el sujeto que sabe de sí a partir de su propia experiencia, que afirma su propia historicidad en el mismo gesto de ponerse como valioso para sí. Este acto de autoafirmación cognitiva y axiológica constituye el punto de partida para el diálogo intercultural auténtico y para la construcción de consensos no alienados ni impuestos.

Sin abandonar los nombres "América Latina" y "Latinoamérica", es creciente el número de estudiosos de problemas y temas latinoamericanos que en los últimos tiempos han inclinado su preferencia hacia la expresión martiana "Nuestra América". El posesivo utilizado por Martí incorpora marcas semánticas específicas del concepto que expresa, abarcador de la complejidad étnica, social y cultural, atravesada por luchas y conflictos de los cuales emerge el "hombre real". Dice Martí:

"Éramos charreteras y togas, en países que venían al mundo con la alpargata en los piés y la vincha en la cabeza. El genio hubiera estado en hermanar, con la caridad del corazón y con el atrevimiento de los fundadores, la vincha y la toga; en desestancar al indio; en ir haciendo lado al negro suficiente; en ajustar la libertad al cuerpo de los que se alzaron y vencieron por ella. ... Cansados del odio inútil ... se empieza, como sin saberlo, a probar el amor. Se ponen en pié los pueblos y se saludan. "iCómo somos?" se preguntan; y unos a otros se van diciendo como 
son. ... [L]as ideas absolutas, para no caer por un yerro de forma, han de ponerse en formas relativas; que la libertad para ser viable, tiene que ser sincera y plena; que si la república no abre los brazos a todos y adelanta con todos, muere la república”. (Martí, 2005: 12, cursiva nuestra).

Los fragmentos de "Nuestra América" transcriptos no operan dentro de la lógica binaria de la modernidad -verdadero/falso, bueno/malo, blanco/de color, civilizado/bárbaro-, que entiende la historia como progreso y está montada sobre un criterio epistemológico que privilegia las sucesiones antes que las simultaneidades, el tiempo antes que el espacio. Al contrario, el texto sintetiza -"hermana"- elementos característicos de otras experiencias del mundo y de la historia, que conllevan formas diferentes de conocer, valorar y actuar. En este sentido constituye una transformación de la matriz colonial del poder, al mismo tiempo que niega creadoramente experiencias anteriores, a través de las cuales venía abriéndose camino desde mediados del siglo XVIII una afirmación de "nosotros los latinoamericanos". Afirmación que registra avances y retrocesos, que no siempre alcanzó formas plenas de autovaloración y que todavía no se ha completado. Podríamos decir, utilizando la expresión de Mignolo, que José Martí realiza de manera anticipada el "giro descolonial", al desligarse de las categorías políticas y epistémicas de la "modernidad occidental".

En su libro sobre La idea de América Latina, Walter Mignolo se propone "excavar en los cimientos imperiales/coloniales de la idea de América Latina para desentrañar la geopolítica del conocimiento desde la perspectiva de la colonialidad" (Mignolo, 2007: 16). Sitúa su reflexión en el paradigma del conocimiento decolonial presente en Guaman Poma de Ayala (San Cristóbal de Suntuntu, 1534 - Lima, 1615) y de manera acentuadamente crítica en las obras de Franz Fanon (Fort-de-France, 1925 - Nueva York, 1961) y Gloria Anzaldúa (Valle del Río Grande, 1942 - Santa Cruz, California, 2004). Desde la perspectiva de la modernidad, la historia puede contarse de muchas maneras. Así por ejemplo, la historia del "descubrimiento de América" tiene una versión cristiana y una marxista, pero aun cuando ellas son "interpretaciones en conflicto", están ambas situadas en el marco epistémico de la modernidad. El semiólogo argentino/ estadounidente introduce la idea de "Heterogeneidad histórico-estructural" para señalar la coexistencia y simultaneidad, como crítica a la idea del progreso histórico. Desde la perspectiva fanoniana habría que considerar la memoria de la trata y explotación de los esclavos, sus consecuencias psicológicas, éticas e históricas. Sería "una perspectiva afrocaribeña centrada en la colonialidad". Dice Mignolo:

"Desde Bartolomé de las Casas, en el siglo XVI, hasta Hegel, en el siglo XIX, y desde Marx hasta Toymbee, en el siglo XX, los textos que se han escrito y los mapas que se han trazado sobre el lugar que ocupa América 
en el orden mundial no se apartan de una perspectiva europea que se presenta como universal. Es cierto que los autores reconocen que hay un mundo y unos pueblos fuera de Europa, pero también es cierto que ven a esos pueblos y a los continentes en que habitan como "objetos», no como sujetos y, en cierta medida, los dejan fuera de la historia. Dicho de otra forma, se trata de sujetos cuyas perspectivas no cuentan. ... la historia es un privilegio de la modernidad, y para tener una historia hay que dejarse colonizar". (Ibídem: 17).

La colonialidad es parte de la modernidad, es su "lado oscuro". El «descubrimiento de América» y el genocidio de esclavos africanos e indios constituyen los cimientos de la modernidad. Excavar en ellos permite comprender cómo nació Occidente y el orden mundial moderno. En este proceso, Mignolo diferencia tres momentos histórico-estructurales hegemónicos: El primero es la entrada de América en la conciencia europea (Renacimiento); el segundo coincide con la aparición de la latinidad como identidad imperial-colonial (Ilustración); el tercero, posterior a la Guerra Fría, presenta transformaciones radicales en la geografía del conocimiento, que cuestionan la ontología y la ideología de la división entre América Latina y América Sajona. Esta última sería la contrapartida de la modernidad, no contada ni reconocida hasta el momento, según afirma el autor.

Sin embargo una mirada detenida sobre la historia de nuestras ideas permite apreciar que la crítica a la modernidad y a la noción de progreso estuvo presente en nuestros pensadores y hombres de acción desde época temprana. Sus prácticas y sus discursos estuvieron vinculadas a la afirmación de la propia historicidad. Para Arturo Roig, lo que importa "respecto de todo hombre, de cualquier cultura, nación o clase social ... no es si ha entrado en la "historia mundial», ... sino tan solo si es "ente histórico», dicho de otro modo, si posee historicidad" (Roig, 1981: 122). Distingue entre un nivel elemental y primario de conciencia histórica que es el centro de una praxis concreta y un nivel de conciencia histórica como aparato teórico que busca interpretar y reorientar aquella praxis. Es en el primer nivel donde tienen lugar las prácticas, los conflictos, las tensiones, las luchas en que arraigan las significaciones. Las cuales no siempre son el resultado de una teoría previamente elaborada; antes bien, pueden presentar un alto grado de ambigüedad. Así por ejemplo, lo que para Toussaint Luoverture, Pétion o Bolívar fue sobre todo una práctica histórica de autoafirmación y ruptura de una totalidad opresiva -plasmada con diverso grado de autoconciencia histórica-, en la reflexión de Joseph-Anténor Firmin (Haití, 1850 - 1911), por mencionar sólo un caso, deviene una teoría de la historia que invierte los términos en los que se sostenía la Historia Universal. (Cfr. Arpini, 2011 y 2010 b y c). 
En trazos gruesos, sin hilar suficientemente fino en las relaciones agónicas en que se produce la significación, Mignolo señala que la «latinidad» es la identidad reivindicada por franceses y adoptada por las elites criollas, que operó una relación de subordinación con relación a los angloamericanos y degradó o borró la identidad de indios y afroamericanos. Según su punto de vista, la lógica de la colonialidad a la que pertenece la idea de "América Latina" sigue vigente en la actualidad mientras se produce una peculiar reestructuración imperial/colonial. Sacar a la luz la perspectiva de quienes han sido silenciados por la misma puede producir cambios radicales. En esta perspectiva, los nuevos proyectos de conocimiento y los movimientos socio-políticos de los pueblos indígenas y de los descendientes de africanos en América Latina, así como de los latinos de Estados Unidos, vuelven obsoleta la «idea de América Latina». La lógica que opera en la comprensión del mundo de los pueblos andinos, ejemplifica Mignolo, se apoya sobre dualismos complementarios. Esta diferencia sería crucial para la transformación decolonial del conocimiento, pues permite desarticular dicotomías categoriales tales como "civilización - barbarie" y otras afines.

"La transformación decolonial es imprescindible si vamos a dejar de pensar en la «modernidad» como un objetivo para verla como una construcción europea de la historia a favor de los intereses de Europa. El diálogo sólo se iniciará cuando la «modernidad» sea decolonizada y despojada de su mítica marcha hacia el futuro, ... cuando deje de imponerse el «monólogo» de la única civilización, la occidental”. (Ibídem: 24).

Las luchas por la significación constituyen momentos en la afirmación de la propia identidad e historicidad. En nuestra América esa afirmación emerge de una relación agónica, de negación de otra concepción del hombre y de la historia, la europea, moderna, organizada sobre las nociones de progreso y civilización. Tiene razón Mignolo, no obstante hay que señalar que esa "transformación decolonial" tiene una historia larga entre nosotros. No se trata de que "ahora vamos a dejar de pensar en la modernidad como objetivo", por la misma razón por la que tampoco está obsoleta la idea de "América Latina" en el sentido bilbaíno o martiano. El relato de la historia es una trama tejida con muchos hilos. En el anverso prevalecen los discursos que lograron imponerse como hegemónicos, pero por el reverso, en tensa relación, es posible encontrar los otros discursos, que narran otras historias entreveradas con las anteriores en el orden de la simultaneidad. Cuando no se las ve, o directamente se las oculta, se produce aquella ceguera epistémica y política, muchas veces culposa, que denunciaba Martí en "Nuestra América" cuando hablaba del "criollo exótico" y de "los letrados artificiales". 
Para completar el panorama en el terreno de las ideas políticas diremos, siguiendo a Rojas Mix, que durante el siglo XX, especialmente durante la Guerra Fría, el término América Latina fue utilizado por las izquierdas de la región en sus esfuerzos por "detener el imperialismo" -Ernesto "Che" Guevara, Salvador Allende, Julio Cortazar, Pablo Neruda y muchos políticos, intelectuales y militantes. Los dictadores, por su complicidad con las políticas "usamericanas", preferían el término "Panamerica"; mientras las derechas conservadoras usaron "Hispanoamérica".

El siglo XXI se inicia con un cambio geopolítico de extensión planetaria, con la hegemonía unipolar de los EEUU, que debe inventarse un nuevo enemigo: el terrorismo. El enfrentamiento "mundo libre - comunismo" fue reemplazado por el "choque de civilizaciones" (Huntington, 1993). Después del 11 de setiembre de 2001, la escena quedó dividida entre George W. Bush y sus aliados contra las fuerzas del mal: Bin Laden, Al Qaeda, Saddam Hussein, etc. Decretada la Guerra de civilizaciones, EEUU usa el miedo de la sociedad civil para mantener su base electoral, al mismo tiempo que extiende sus intereses económicos.

Muchos países buscan distanciarse de la política "usamericana" y del modelo neoconservador. "Desde Venezuela hasta la Argentina ... el hemisferio está alineándose fuera del control del Departamento de Estado" (Rojas Mix, 2009: 38). Pueblos de América Latina se han levantado en contra de la religión del mercado y han producido una alianza de culturas, donde las antiguas renacen a la vida pública junto a los sectores más desfavorecidos. Nuevos discursos de identidad, nuevos proyectos de integración que buscan la autonomía continental, la cancelación del colonialismo y el desarrollo de la región por diferentes medios. Bolivarismo, latinoamericanismo, indigenismo, afroamericanismo, negritud se unen para recuperar el posesivo de Martí: nuestra América.

\section{Vivir y filosofar en América Latina}

Veamos las siguientes expresiones:

"Conversando un día con un colega francés ... se puso violento cuando empezamos a hablar del pensamiento y la filosofía latinoamericanos, para afirmarme con una sonrisa sobradora que en América no había ni podía haber filosofía. ... No ha faltado incluso quien me afirmara que «los latinoamericanos no necesitan pensar». Inconscientemente, mis interlocutores reproducían un estereotipo interiorizado del eurocentrismo, que ha hecho la gran repartición entre la razón, patrimonio específico de occidente; y lo irracional o no-racional -que puede ser el «realismo mágico» o lo "real maravilloso», lo literario pero, jamás lo filosóficocomo lo propio de las sociedades no-occidentales. Desgraciadamente, y 
más que a menudo, es ésta la óptica con que se estudia América”. (Rojas Mix, 1991: 22).

"La Filosofía Latinoamericana se ocupa de los modos de objetivación de un sujeto, a través de los cuales se reconoce y se autoafirma como tal. Esos modos de objetivación son, por cierto históricos y no siempre se logra a través de ellos una afirmación se subjetividad plena. ... Aquella afirmación de sujetividad es condicionante, pero también e inevitablemente, condicionada. Hacemos nuestras circunstancias, más, también ellas nos hacen. Debido a esto la historia de aquel acto de afirmación nos muestra un elevado grado de contingencia y el desarrollo del proceso de autorreconocimiento y de autoposición muestra comienzos y recomienzos" (Roig, 2011: 113).

Los párrafos transcriptos dejan ver uno de los desafíos teóricos más persistentes del quehacer filosófico latinoamericano, el de la afirmación crítica de ese mismo quehacer y del sujeto que lo lleva adelante como problema de la vida filosófica misma. Nos interesa mostrar la actualidad del problema recurriendo, aunque pueda parecer paradójico, a dos de nuestros filósofos del siglo XIX, Juan Bautista Alberdi en sus escritos tempranos, anteriores a 1852 (Cfr. Ramaglia, 2010) y José Martí, a través de escritos poco elaborados como los de sus cuadernos de apuntes.

Es generalizada la afirmación de que el primero en plantear la necesidad de una filosofía americana fue Juan Bautista Alberdi (Tucumán, 1810 - NueillySur-Seine, 1884) en sus "Ideas para presidir la confección del curso de Filosofía Contemporánea en el Colegio de Humanidades" (Montevideo, 1840). Dice Alberdi:

"Nuestra filosofía, pues, ha de salir de nuestras necesidades. Pues, según estas necesidades, ¿cuáles son los problemas que la América [se refiere a la América Latina] está llamada a establecer y resolver en estos momentos? Son los de la libertad, de los derechos y goces sociales de que el hombre puede gozar en el más alto grado en el orden social y político; son los de la organización pública más adecuada a las exigencias de la naturaleza perfectible del hombre en el suelo americano. (Alberdi, 1996: 98).

En el Fragmento preliminar al estudio del derecho, exhorta:

"Gobernémonos, pensemos, escribamos y procedamos en todo, no a imitación de pueblo alguno en la tierra, sea cual fuere su rango, sino como lo exige la combinación de las leyes generales del espíritu humano con las individuales de nuestra condición nacional" (Alberdi, 1996: 66)

Arturo Roig reflexiona, a partir de los textos alberdianos, acerca de la necesidad de un filosofar americano. Sostiene que el problema de la posibilidad de una filosofía americana tuvo su origen con la generación romántica de 1837, 
ante la necesidad de dar sentido a la experiencia histórica de la Independencia. Lo acontecido en el Río de La Plata, en mayo de 1810, en cuanto sustancia histórica "debía ser asumido por la idea y a su vez la idea debía ser justificada si se pretendía que ella tuviera realmente eficacia histórica ... [Así, Mayo] se integraba en un proceso de recreación, se convertía en una tarea filosófica" (Roig, 1970, 117-118).

Alcanzar el sentido de Mayo implicaba consolidar la emancipación desde el pensamiento. De esta manera aparece en Alberdi enunciado por primera vez el tema de una filosofía americana. Según la interpretación roigeana, en el Fragmento preliminar al estudio del derecho, Alberdi propone hacer una "filosofía de la filosofía" y descubre que ésta, como resultado de la propia actividad de filosofar, "se ha hincado en la temporalidad". Gracias a tal hinchamiento es posible afirmar un nosotros diferenciado de los demás y un quehacer filosófico auténtico que no cae en el plagio o imitación servil de la exótico. No sólo porque es un pensar de la propia situación histórica, sino de la propia praxis teórica. Se trata de una filosofía que no rehúye la tensión dialéctica con la propia situación socio-histórica, ni la no menos dialéctica relación teoría-praxis.

Cabe, entonces, preguntar como lo hace el filósofo mendocino, si la expresión alberdiana "filosofía americana" es sinónimo de "filosofía de América. La respuesta es, desde luego, afirmativa atendiendo al sentido subjetivo y objetivo del de. Esto es, filosofía de tema americano y filosofía del hombre americano, o lo que es lo mismo: filosofía sobre América y desde América. Tal vez el mismo Alberdi, condicionado por su tiempo, no pensó la diferencia epistemológica que estaba instalando, ni tampoco consideró toda la diversidad involucrada en la idea del hombre americano, tal vez sólo pensó en los criollos, pero esas limitaciones no invalida el gesto con el que queda señalada una grieta en que se constituye -está constituyéndose permanentemente- la filosofía latinoamericana. Al poner en juego al sujeto, el filosofar no queda reducido al examen filosófico de la historia o la cultura de América, es decir, no queda determinado exclusivamente por el objeto, sino que cualquier asunto puede ser contenido de una reflexión realizada desde el propio horizonte de comprensión, "como una función de la existencia americana".

Las declaraciones alberdianas del Fragmento preliminar al estudio del derecho y de las Ideas para presidir la confección del curso de filosofía contemporánea en el Colegio de Humanidades (Montevideo) constituyen "el primer intento de sincronizar el pensar filosófico con la realidad histórica”. (Cfr. Roig, 1970). El término "sincronizar" es utilizado por Roig para referirse a un pensar que surge de un estar puesto para sí plenamente consciente, es decir del modo de relación entre el pensar con su realidad histórica. Si el momento de las guerras de independencia supuso el ponerse para sí, el momento sintetizado en los textos de Alberdi 
supuso además una exigencia de autoconciencia nacional explícita. Esto es la necesidad de considerar como valioso el conocerse por sí mismo, o dicho de otro modo, un ponerse en el orden del concepto. Se trata, según Roig, de sucesivos grados de desarrollo del para sí, ya que es una tarea permanente y dialéctica de enriquecimiento, que va promoviendo nuevos horizontes de autoconocimiento. Justamente porque se reconoce la historicidad propia, tanto del sujeto como del objeto del filosofar, quedan rechazadas todas aquellas teoría que de algún modo pretenden colocarse en el punto cero de la reflexión.

Otra experiencia de autorreconocimiento y autoafirmación es la que surge de los escritos martianos durante su estancia en Guatemala (1877 - 1878). Entre los apuntes de Martí se encuentran un conjunto de fragmentos y de juicios relativos a la filosofía, que corresponden a la época en que fue catedrático en la Escuela Normal Central de Guatemala. A pesar de su brevedad contienen todo un programa del quehacer filosófico, cuya vigencia llega hasta nuestros días. Uno de los fragmentos dice:

"Puedo hacer dos libros: uno dando a entender que sé lo que han escrito los demás:

-placer a nadie útil, y no especial mío.

Otro, estudiándome a mí por mí, placer original e independiente. Redención mía por mí, que gustaría a los que quieran redimirse.

Prescindo, pues, de cuanto sé, y entro en mi Ser.

¿Que qué somos? ¿Que qué éramos? ¿Que qué podemos ser?" (Martí, 1975, vol. 19: 360)

El texto nos coloca ante dos programas filosóficos posibles, pero diferentes. Uno consiste en reproducir la letra de la filosofía, pero como letra muerta, como pura erudición, sin más pretensiones que una "visión monumental o anticuaria" del pasado filosófico, al que se venera como cumbres de la humanidad pero que permanece exterior a nosotros. Saber que pasa a través de nosotros sin dejar huella, sin conmovernos ni transformarnos. El otro consiste en apropiarse del poder de la palabra para decir de sí, para "redimirse", es decir -según una de las posibles acepciones de esta palabra- para liberarse. Se trata de conocerse a sí mismo, no de la manera en que un sujeto conoce a un objeto, sino en un sentido más complejo, próximo a lo que Foucault llama la "hermenéutica del sujeto", en el que el conocimiento de sí está asociado al cuidado de sí. (Cfr. Foucault, M., 1999: 275 - 288). Ahora bien, Martí no propone un conocimiento y un cuidado egoístas de sí -como es el caso de la Meditaciones de Descartes y de su moral provisional-, sino que pasa del yo al nosotros, del presente al futuro: “iqué somos, qué éramos, qué podemos ser?”. Preguntas que implican una práctica de autoconocimiento y autovaloración de un sujeto 
plural, de un "nosotros" que recoge la diversidad de las formas de vida de nuestra América, que trae el pasado al presente como experiencia auténtica del pensar -es decir, como legado-, que trastorna las certezas más superficiales y también las más profundas, e inaugura posibilidades de transformación, de creación al colocarse ante el abismo de la novedad.

En este sentido la experiencia filosófica es portadora de singular riqueza y fecunda en posibilidades. No es sólo un problema del conocimiento, sino que involucra también las dimensiones axiológica y estética. Conocimiento, valoración y goce se entreveran en ella, y se exterioriza en conceptos, pero no como meras palabras, sino como narración, como relato de sí de un sujeto -nunca singular- que ha sido atravesado y transformado -"redimido", es decir "liberado"-, por la experiencia del filosofar.

Este programa filosófico esbozado por Martí exige una lectura crítica de la realidad, requiere un examen del pasado y del presente en vistas de su transformación, pero también un examen del examen, del propio y del ajeno:

"Tenemos que para conocer es necesario examinar: que la fuente más creíble de verdad es nuestro propio examen; que el examen, medio seguro de conocer la aplicación de nuestra aptitud de conocer a la cosa cognoscible: [es] observación, -y el pensamiento sobre lo observado: reflexión-"...

" ¿ $[\mathrm{Q}]$ ué hemos de hacer para saber? Examinar con nuestro criterio el examen que ha hecho el criterio ajeno, o, lo que es más seguro, examinar por nosotros mismos. ... Luego nosotros mismos somos el primer medio del conocimiento de las cosas, el medio natural de investigación, el medio natural filosófico". (Ibídem: 362 - 364).

En este sentido cabe el ejercicio de la sospecha y la crítica: "La crítica no es la censura; es sencillamente y hasta en su acepción formal -en su etimologíaes eso, el ejercicio del criterio". (Ibídem: 366). Las nociones de examen propio y crítica dejan diseñado en el pensamiento de Martí un programa de Filosofía Crítica Latinoamericana.

$\mathrm{Si}$ ahora consideramos el desarrollo de la filosofía en nuestras escuelas y universidades, encontraremos una masa de producción teórica de escaso o nulo valor creativo, funcional a circunstancias determinadas. Esto no es razón para descalificar en bloque la producción académica. Antes bien, el problema no es tanto el ámbito -académico o no académico- donde se propicia la práctica de pensamiento, sino el de su relación con la realidad y con su propia historia construida como referencia.

La dependencia económica y el colonialismo cultural marcan la cuestión de la identidad. Desde Andrés Bello en adelante, la mayoría de los intelectuales latinoamericanos han encarado la tarea de terminar con el colonialismo, el 
cual se reproduce a través de dos operaciones intelectuales: la incapacidad de construir el propio pensamiento como referencia y la reflexión mediatizada. Rojas Mix lo expresa de manera contundente: no se trata de dar la espalda al pensamiento universal, "debemos servirnos de él, pero no servir a", "ver con ojos propios, no sólo lo nuestro, sino también lo impropio", para evitar que "los árboles de la referencia ajena nos impidan ver el bosque de nuestro pensamiento", "revisar el mundo y devolverlo latinoamericano como, como creación” (Rojas Mix, 1991: 374 y 384). Para nuestro tiempo, como para el de Simón Rodríguez, el de Martí o de Mariátegui, la palabra de pase es “creación”.

Durante el siglo XX, y hasta el presente, la pregunta por la situación de nuestras naciones, renovó el potencial contenido en la idea de comienzos y recomienzos del filosofar, dando lugar a desarrollos diversos. Frente a los cambios globales y a la nueva faz del imperialismo, se impone un replanteo y renovación del quehacer filosófico, entre cuyas tareas ineludibles se cuentan:

- El problema del sujeto y la construcción de la identidad, una vez más las preguntas ¿qué somos?, ¿qué éramos?, ¿qué queremos ser?

- El hacerse cargo de la diferencia desde la que emerge nuestro filosofar, de sus condiciones de posibilidad, su especificidad y su potencialidad.

- El reconocimiento de las formas ensayísticas y narrativas propias de nuestra filosofía, es decir de los relatos a través de los cuales se articula la historia de nuestras ideas, que implica también la crítica de las formas ideológicas.

- El examen de las tensiones antropológicas, epistemológicas, axiológicas y políticas implicadas en la tríada diversidad - integración - interculturalidad.

- La revisión crítica de los problemas de la formación filosófica y la filosofía de la educación, asumidos ambos como asuntos filosóficos.

Por cierto no es un listado exhaustivo. En todo caso se trata de tomar conciencia de la terea de la filosofía dentro del sistema de conexiones de nuestra época, ya que la liberación y la integración de los pueblos latinoamericanos es un proceso histórico, social, política y culturalmente complejo, que exige tensar al máximo la cuerda de la creatividad. A dicho proceso se suma la filosofía como una determinación histórica más. 


\section{Referencias bibliográficas}

ALBERDI, Juan Bautista (1955) Fragmento preliminar al estudio del derecho (1837). Buenos Aires: Hachette.

ALBERDI, Juan Bautista (1996) Escritos de Juan Bautista Alberdi: el redactor de la ley. Presentación y selección de textos por Oscar Terán, Buenos Aires: Universidad nacional de Quilmes.

ARDAO, Arturo (1963) Filosofía de lengua española. Montevideo: Alfa.

ARDAO, Arturo (1980) Génesis de la idea y el nombre América Latina. Caracas: Centro de Estudios Latinoamericanos Rómulo Gallegos - Ministerio de la Secretaría de la Presidencia de la República de Venezuela.

ARDAO, Arturo (1991) Romania y América Latina. Montevideo: Biblioteca de Marcha Universidad de la República.

ARDAO, Arturo (1992) España en el origen del nombre América Latina. Montevideo: Biblioteca de Marcha - Universidad de la República.

ARDAO, Arturo (1993) América Latina y la latinidad. México D.F.: Centro Coordinador y Difusor de Estudios Latinoamericanos, UNAM, Colección "500 años después”.

ARPINI, Adriana María (1993) "El latinoamericanismo de los argentinos" en Roig, Arturo Andrés (compilador), Argentina del 80 al 80. Balance social y cultural de un siglo, México D.F. Centro Coordinador y Difusor de Estudios Latinoamericanos (CCyDEL): UNAM.

ARPINI, Adriana María (2010 a) "Filosofía y política en el surgimiento de la Filosofía Latinoamericana de la Liberación”, en SOLAR Revista de Filosofía Iberoamericana, no 6, año 6. Lima: Universidad Científica del Sur; pp.125-150.

ARPINI, Adriana María (2010 b) “Joseph-Anténor Firmin: vindicación de la raza negra y de la unión antillana”, en Arpini, Adriana y Jalif de Bertranou, Clara (editoras), Diversidad e integración en Nuestra América, Volumen I: Independencia, Estados nacionales e integración continental (1804-1880). Buenos Aires: Biblos.

ARPINi, Adriana María (2010 c) "François Toussaint-Louverture y la independencia de Haití. Para una historia episódica del bicentenario", en: Arpini, Adriana y Jalif de Bertranou, Clara (editoras) Diversidad e integración en Nuestra América, Volumen I: Independencia, Estados nacionales e integración continental (1804-1880). Buenos Aires: Biblos; pp. 27 -44.

ARPINI, Adriana María (2011) "Igualdad de razas e interpretación de la historia en un discurso del haitiano Joseph-Antenor Firmin”, en Erasmus. Revista para el diálogo intercultural, año XIII, nº 1. Río Cuarto: Ediciones del ICALA; pp.65 - 88.

ARPINI, Adriana y Jalif de Bertranou, Clara (editoras) (2010) Diversidad e integración en Nuestra América, Volumen I: Independencia, Estados nacionales e integración continental (1804-1880). Buenos Aires: Biblos; pp.327 - 342.

BILBAO, Francisco (1866) Obras Completas editadas por Manuel Bilbao. Buenos Aires. Consultada en Proyecto Filosofía en Español, http:/www.bicentenarios.es/ doc/8560622.htm, (15/01/2013).

DE OTO, Alejandro (2008) "Historia de la teoría. Crítica poscolonial y después", en Pasado por-venir. Revista de historia, año 3, no 3, Trelew: Departamento de Historia, FHCS, UNPSJB : pp.85-106. 
DÍAZ DE GAMARRA Y DÁVALOS, Juan Benito (1947) "Errores del entendimiento humano" en Tratados, Edición y prólogo de José Gaos. México: UNAM.

FOUCAULT, Michel (1999) Estética, ética y hermenéutica. Obras Esenciales, volumen II. Traducción de Ángel Gabilondo. Barcelona: Paidós.

JALIF DE BERTRANOU, Clara Alicia (2003) Francisco Bilbao y la experiencia literaria de América. La propuesta de una filosofía americana. Mendoza: EDIUNC.

MARTí, José (2005) Nuestra América y otros escritos. Buenos Aires: El andariego. Martí, José (1975) Obras Completas. La Habana: Editorial de Ciencia Sociales.

MIGNOLO, Walter (2007) La idea de América Latina. La herida colonial y la opción decolonial, Traducción de Silvia Jawerbaum y Julieta Barba. Barcelona: Gedisa.

OLALLA, Marcos (2010) “José María Torres Caicedo: sentido universalista del proyecto de unidad latinoamericana” en Arpini, Adriana y Jalif de Bertranou, Clara (editoras) Diversidad e integración en Nuestra América, Volumen I: Independencia, Estados nacionales e integración continental (1804-1880). Buenos Aires: Biblos.

OSSANDÓN Buljevik, Carlos (2003) "Nuestra América”, en Salas Astrain, Ricardo, (Coordinador académico), Pensamiento crítico latinoamericano. Conceptos fundamentales, Volumen II. Santiago de Chile: Ediciones Universidad Católica Silva Henríquez: pp. 719-127.

RAMAGLIA, Dante (2010) “Juan Bautista Alberdi: los márgenes de la integración en el proyecto civilizatorio”, en Arpini, Adriana y Jalif de Bertranou, Clara (editoras), Diversidad e integración en Nuestra América, Volumen I: Independencia, Estados nacionales e integración continental (1804-1880). Buenos Aires: Biblos; pp.187-216.

RAMOS, Julio (1989) Desencuentro de la modernidad en América Latina. Literatura y política en el siglo XIX. México: Fondo de Cultura Económica.

ROIG, Arturo Andrés (1979) "Los ideales bolivarianos y la propuesta de una Universidad Latinoamericana Continental”, en Latinoamérica. Cuadernos de Cultura Latinoamericana, no 4, Centro de Estudios Latinoamericanos. México: UNAM.

ROIG, Arturo Andrés (1981) Teoría y crítica del pensamiento latinoamericano, México: Fondo de Cultura Económica.

ROIG, Arturo Andrés (1993) Rostro y filosofía de América Latina. Mendoza: EDIUNC. (Segunda edición corregida y aumentada, con el título Rostro y filosofía de nuestra América. Buenos Aires, Una Ventana, 2011).

ROIG, Arturo Andrés (2000) “Globalización y filosofía latinoamericana” en Rico, Álvaro y Yamandú Acosta (Compiladores). Filosofía latinoamericana, globalización y democracia. Montevideo: Nordan.

ROIG, Arturo Andrés (2002) Ética del poder y moralidad de la protesta. Respuestas a la crisis moral de nuestro tiempo. Mendoza: EDIUNC.

ROIG, Arturo Andrés (2008) El pensamiento latinoamericano y su aventura. Buenos Aires: El Andariego. [Primera edición: Centro Editor de América Latina, Buenos Aires, 1994].

ROIG, Arturo Andrés (2009) Teoría y crítica del pensamiento latinoamericano. Buenos Aires: Una ventana.

ROIG, Arturo Andrés (2011) Rosto y filosofía de nuestra América. Buenos Aires: Una ventana. 
ROJAS MIX, Miguel (1991) Los cien nombres de América. Eso que descubrió Colón. Barcelona: Lumen.

ROJAS MIX, Miguel (2009) “América Latina”, en Biagini, Hugo y Arturo Roig, Diccionario del pensamiento alternativo (Segunda Edición). Buenos Aires: Biblos, UNLa; pp. $36-38$.

SANTOS, Boaventura de Sousa (2004) La caída del Angelus Novus. Ensayos para una nueva teoría social y una nueva práctica política. Bogotá: ILSA - Universidad Nacional de Colombia.

TORRES CAICEDO, José María (1882) “La América Anglosajona y la América Latina” en Ardao, Arturo (1993); pp. 146-152. 